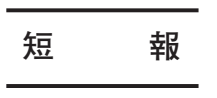

\title{
人間ドック受診者を対象とした静岡県中西部地区における 森林散策頻度に関する大規模調査
}

\author{
森田え $2^{*, 1} \cdot$ 内藤真理子 ${ }^{1} \cdot$ 西尾和子 ${ }^{1} \cdot{\text { 石田喜子 }{ }^{1} \cdot \text { 菱田朝陽 }}^{1}$ \\ 若井建 志 $^{1} \cdot$ 浅井八多美 ${ }^{2} \cdot$ 浜 島 信 $\dot{2}^{1}$
}

\begin{abstract}
静岡県中西部地区において, 35〜69 歳の人間ドック受診者を対象にして, 森林散策の頻度に関して自記式質問紙による大規 模な実態調查を行った。解析対象者は 4,666 人（男性 3,174 人，女性 1,492 人：平均年齢（標準偏差） 52.1 (8.7) 歳）で, 森林 散策をする頻度が月 1 回以上の人は，男性では 644 人 (20.3\%), 女性では 259 人 ( $17.4 \%)$, 年 1 回以上の人は男性では 1,818 人 $(57.3 \%)$, 女性では 798 人 $(53.5 \%)$ であった。性別では男性の方が, 年齢別では高年齢の人の方が, 有意に森林に高い頻 度で行っていた。また, 森林散策が好きな人ほど有意に高い頻度で森林に行っていた。今後は, 都市公園の利用頻度も含め, 他地域での森林散策頻度も検討する必要があると考えられる。

キーワード：森林散策頻度, 静岡県, 大規模調査, 人間ドック受診者
\end{abstract}

\begin{abstract}
Emi Morita, ${ }^{* 1}$ Mariko Naito, ${ }^{1}$ Kazuko Nishio, ${ }^{1}$ Yoshiko Ishida, ${ }^{1}$ Asahi Hishida, ${ }^{1}$ Kenji Wakai, ${ }^{1}$ Yatami Asai, ${ }^{2}$ and Nobuyuki Hamajima ${ }^{1}$ (2010) A Large-scale Survey of Health Check-up Visitors in the West-Central Area of Shizuoka Prefecture Regarding the Frequency of Walking in Forested Areas. J. Jpn. For. Soc. 92: 110-114. A large-scale survey regarding the frequency of walking in forested areas was conducted on health check-up visitors living in the West-Central area of Shizuoka Prefecture. Participants were people, aged 35 to 69 years, who underwent health check-ups. A total of 4,666 participants (3,174 men, 1,492 women: mean \pm SD age; $52.1 \pm 8.7$ years) were included in the analysis. Of the participants, $20.3 \%$ of men $(n=644)$ and $17.4 \%$ of women $(n=259)$ responded that they walked in a forested area at least once a month; and $57.3 \%$ of men $(n=1,818)$ and $53.5 \%$ of women $(n=798)$ responded that they walked in forested areas at least once a year. Men had a significantly higher frequency of walking in forested areas than women. The higher the age group, the significantly higher was the rate of walking in forested areas. The higher the level of enjoyment of forest walking, the significantly higher was the frequency of walking in such areas. In future studies, frequencies of visiting to green parks and walking in forested areas should be revealed on other areas.
\end{abstract}

Key words: frequency of forest walking, Shizuoka Prefecture, large-scale survey, health check-up visitors

\section{I. は じめに}

日本では，国土の $67 \%$ が森林であり，森林は最も典型 的な自然環境である（林野庁, 2007）。森林は, 木材生産, 生物多様性の保全, 水源涵養などの機能に加え, 保健休養 や環境教育の場として, 余㗇などに楽しみのために行く所 にもなっている。余㗇に都市住民などが森林に行くことは, 山村地域の住民にとっては, 特用林産物・農産物の販売な どによる収入を得る機会や，観光産業などでの雇用の機会 が増えることになる（林野庁，2008）。さらに，中山間地 域ではこれらの交流などにより，定住化をする人が増えて 山村が活性化することが期待されている（林野庁, 2008)。

また，森林を保健休養の場としてみた場合，急性の効果 がみられても,それがただちに健康に結びつくとは限らず, 一般的に健康づくりは, 運動でも食生活でも 1 回だけでは なく,習慣として行うことが必要であると考えられている。 よって, 今後, 中山間地域の振興や保健休養の場としての 活用を推進していくためには, リピーターの数を増やした
り，より多くの人に森林に足を運んでもらう必要がある。 そのためには, 現状で一般の人が, どの程度の頻度で, 森 林に行っているのかを把握することが必要である。

森林散策の頻度に関しては, 特定の公園や森林に訪れる 回数は，これまでにも報告されており（大石，2005; 國光， 2005; 山根, 1989), 全般的な森林散策頻度に関しての報告 も, 白神山地域来訪者, 東京大学千葉演習林や京都大学 芦生演習林に来た人を対象にしたものがある（大石, 2005; 森田ら, 2009; Morita et al., 2009)。しかしながら, これら の全般的な森林散策頻度に関しての調查は, 既に森林に来 ている人を対象にしているため，一般集団よりも森林散策 頻度高い可能性がある。よって, 一般住民での森林散策頻 度の実態を把握することが必要である。

一般住民を対象とした内閣府の「森林と生活に関する世 論調查」では, 過去 1 年に, どのような目的で森林に行っ たのかという項目が含まれており，2007年の調査では, 行ったことがないと回答した人は $27.3 \%$ に過ぎず， $72.7 \%$ の人が過去 1 年間に何らかの目的で森林に行ったことが推

\footnotetext{
*連絡先著者（Corresponding author） E-mail：emorita@med.nagoya-u.ac.jp

1名古屋大学大学院医学系研究科 $\bar{T}$ 466-8550 名古屋市昭和区鶴舞町 65 (Graduate School of Medicine, Nagoya University, 65 Tsurumai-cho, Showa-ku, Nagoya 466-8550, Japan)

2 聖隷福祉事業団三方原ベテルホームき 431-1304 浜松市細江町中川 7421-1（Mikatahara Bethel Home, Seirei Social Welfare Community, 7421-1 Nakagawa, Hosoe-cho, Hamamatsu 431-1304, Japan)

(2009 年 9 月 30 日受付; 2009 年 11 月 2 日受理)
} 
測される（内閣府，2007）。しかしながら，この世論調查 からは，過去 1 年に， 1 回以上，森林に行った人の割合は 推測できるものの, 具体的に, 年に何回程度, 森林に行っ ているのかという頻度に関する情報は含まれていない。ま た，世論調査は，森林散策頻度が，どのような要因と関連 があるのかも明らかにしていない。

本研究は, 大学演習林に来た人より, 一般住民に近いと 考えられる集団で, 森林散策の頻度の調查を大規模に行い, 森林散策頻度の実態を明らかにするとともに，森林散策の 頻度と関連がある要因についても検討することを目的とし た。

\section{II. 方法}

本研究は, 森林散策の頻度が大学演習林に来た人より一 般集団に近いと考えられる日本多施設共同コーホート研究 の静岡地区の参加者に対して実施した。日本多施設共同 コーホート研究は，主にがんに関して遺伝的体質と生活習 慣との関連を検証することを目的として全国 10 施設/大学 で行われており, 約 20 年間に渡ってがんの発症や死亡を 追跡調查する研究である。 20 年間のがん罹患や死亡を観 察するために, 対象年齢は 35 歳から 69 歳としている（The J-MICC Study Group, 2007)。2006 年 1 月から 2007 年 12 月に, 静岡県浜松市の聖隷予防検診センターで, 1 泊人間 ドック，若しくは日帰り人間ドックを受診した人のうち， 研究対象者 (35 歳から 69 歳で, 静岡県中西部に住民票が ある人)であった 13,740 人に対して, 研究の概要を説明し, 研究協力の同意が得られた 5,040 人を参加者とした（Asai

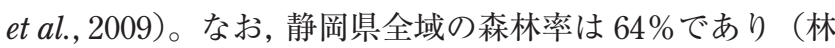
野庁, 2007)，2006 年 1 月時点での対象地域の人口総計は, 約 250 万人であった（静岡県生活・文化部県民生活総室生 活統計室, 2006)。

自記式質問紙を用い，職業，森林散策の頻度（「都市公 園を除く」と明記；1：週 1 回以上～6:ほとんど行かない), 森林散策の好き嫌い（1：とても好き〜 5 ：とても嫌い）を 尋ねた。森林散策の頻度の質問で,「都市公園を除く」と 明記した理由は，(1)都市公園へ行く頻度は，居住地近辺で の都市公園の有無に依存している可能性があり（Takano et al., 2002), (2)都市公園では立木密度が高くない場合も多 く，森林ではないとみなす人もいる一方で，わずかでも樹 木が生えていれば森林とみなす人がいるとも考えられ，判 断が分かれる可能性があり，(3)将来，森林散策頻度と健康 との関連を検討する際には，日常生活の中で都市公園の中 を通った場合と，森林地域に出かけて行った場合では，運 動量が異なるためである。

解析は，森林散策頻度の男女の差，森林散策の好き嫌い の男女の差，就労者と非就労者の森林散策の差を Pearson の $\chi^{2}$ 検定, 森林散策の頻度と年齢（10 歳刻み：30 歳代〜 60 歳代), 森林散策の頻度と森林散策の好き嫌い，年齢層 と森林散策の好き嫌いの関連については, Spearmanの相 関係数を求めた。連続量は, $t$ 検定を行った。有意水準は $5 \%$
とし, 統計解析ソフトゥエアは, SPSS 14.0J for Windows を使用した。

本研究は, 名古屋大学医学部生命倫理委員会の承認を得 て実施した。

III. 結果

2009 年 3 月末時点で研究同意の撤回をしていない 5,031 人のうち，森林散策の頻度に対して有効回答をした 4,666 人（男性 3,174 人, 女性 1,492 人：平均年齢（標準偏差） 52.1 (8.7) 歳) を解析対象とした。平均年齢（標準偏差） は，男性 52.6（8.7）歳，女性 51.0（8.6）歳であった。対 象者の職業を表-1に示す。なお, 林業に従事している人は, 男性 5 人 $(0.2 \%)$, 女性 1 人 ( $0.1 \%)$ であった。

森林散策の頻度（年齢層別・男女別）を表-2 に示す。 月 1 回以上, 森林散策をしている人は 903 人 $(19.4 \%)$, 年 1 回以上，森林に行っている人は 2,616 人 (56.1\%) で あった。男女別では, 月 1 回以上の人は, 男性では 644 人 (20.3\%)，女性では 259 人 (17.4\%), 年 1 回以上の人は男 性では 1,818 人 $(57.3 \%)$, 女性では 798 人 $(53.5 \%)$ であった。

次に，森林散策の頻度の男女差を検討したところ有意な 差があり $(p=0.012)$, 男性の方が高い頻度で森林に行っ ていた。年齢と森林散策の頻度の関連は, 男女ともに有 意に弱い相関がみられ，高年齢の人ほど高い頻度で森林 に行く割合が高かった（男性： $R=-0.17, p<0.001$, 女性： $R=-0.16, p<0.001$ )。月 1 回以上，森林散策をしている 割合は, 男性では 30 歳代 $9.5 \%, 40$ 歳代 $13.2 \%, 50$ 歳 代 $20.8 \%$ ，60 歳代 $32.1 \%$ ，女性では，30 歳代 $11.2 \% ， 40$ 歳代 $10.3 \% ， 50$ 歳代 $19.7 \% ， 60$ 歳代 $29.1 \%$ であった。年 1 回以上森林散策をしている割合は, 男性では 30 歳代 $47.2 \% ， 40$ 歳代 $52.4 \% ， 50$ 歳代 $57.5 \% ， 60$ 歳代 $66.4 \%$, 女性では 30 歳代 $49.5 \%, 40$ 歳代 $47.4 \%, 50$ 歳代 $55.4 \%$, 60 歳代 $62.8 \%$ であった。

また, 森林散策の頻度を就労者 (男性 2,896 人, 女性 1,148 人）と非就労者（男性 278 人，女性 344 人）で比較した ところ, 非就労者は就労者に比べ有意に森林散策頻度が 高かった（男性/女性 : $p<0.001$ )。なお, 非就労者（男性 $64.1 \pm 4.0$ 歳, 女性 $56.0 \pm 9.3$ 歳）は, 就労者（男性 $51.5 \pm$ 8.2 歳, 女性 $50.0 \pm 7.8$ 歳) に比較して有意に年齢が高く（男 性/女性 : $p<0.001)$, 森林散策の好きな人の割合も高かっ た（男性 $p=0.013 ＼mathrm{~ ， 女 性 ~} p=0.001$ ）。

表-1. 参加者の職業（男女別）

\begin{tabular}{|c|c|c|c|c|}
\hline & \multicolumn{2}{|c|}{ 男性 } & \multicolumn{2}{|c|}{ 女性 } \\
\hline & $n$ & $\%$ & $n$ & $\%$ \\
\hline 自営業・社長 & 391 & $12.3 \%$ & 123 & $8.2 \%$ \\
\hline 正社員 & 1650 & $52.0 \%$ & 326 & $21.8 \%$ \\
\hline 公務員 & 637 & $20.1 \%$ & 311 & $20.8 \%$ \\
\hline 契約社員 & 98 & $3.1 \%$ & 63 & $4.2 \%$ \\
\hline パートタイマー・アルバイト等 & 115 & $3.6 \%$ & 320 & $21.4 \%$ \\
\hline 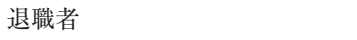 & 269 & $8.5 \%$ & 61 & $4.1 \%$ \\
\hline 専業主婦（夫） & 0 & $0.0 \%$ & 255 & $17.1 \%$ \\
\hline 非就労その他 & 7 & $0.2 \%$ & 22 & $1.5 \%$ \\
\hline 回答不明 & 7 & $0.2 \%$ & 11 & $0.7 \%$ \\
\hline
\end{tabular}


表-2. 年齢層別の森林散策頻度（男女別）

\begin{tabular}{|c|c|c|c|c|c|c|c|c|c|}
\hline \multirow[t]{2}{*}{ 頻度 } & \multicolumn{2}{|c|}{ 合計 } & 週 1 回以上 & 月 $2 \sim 3$ 回 & 月 1 回 & 年数回 & 年 1 回 & $\begin{array}{l}\text { ほとんど } \\
\text { 行かない }\end{array}$ & \multirow{2}{*}{$\begin{array}{c}\text { Spearman } の \\
\text { 相関係数 }\end{array}$} \\
\hline & $n$ & $\%$ & $\%$ & $\%$ & $\%$ & $\%$ & $\%$ & $n \quad \%$ & \\
\hline 全体 & 4666 & & $235(5.0)$ & $274(5.9)$ & $394 \quad(8.4)$ & $1227(26.3)$ & 486 (10.4) & $2050(43.9)$ & \\
\hline \multicolumn{10}{|l|}{ 男性 } \\
\hline 30 歳代 & 252 & $7.9 \%$ & $3(1.2)$ & $8(3.2)$ & $13(5.2)$ & $72(28.6)$ & $23(9.1)$ & $133(52.8)$ & $R=-0.17$ \\
\hline 40 歳代 & 937 & $29.5 \%$ & $30(3.2)$ & $32(3.4)$ & $62(6.6)$ & $254(27.1)$ & $113(12.1)$ & $446(47.6)$ & $p<0.001$ \\
\hline 50 歳代 & 1246 & $39.3 \%$ & $59(4.7)$ & $86(6.9)$ & $114(9.1)$ & 331 (26.6) & $127(10.2)$ & $529(42.5)$ & \\
\hline 60 歳代 & 739 & $23.3 \%$ & $72(9.7)$ & 84 (11.4) & $81(11.0)$ & $194(26.3)$ & $60(8.1)$ & $248(33.6)$ & \\
\hline 小計 & 3174 & $100.0 \%$ & 164（ 5.2） & $210(6.6)$ & $270(8.5)$ & 851(26.8) & $323(10.2)$ & $1356(42.7)$ & \\
\hline \multicolumn{10}{|l|}{ 女性 } \\
\hline 30 歳代 & 188 & $12.6 \%$ & $1(0.5)$ & $9(4.8)$ & $11(5.9)$ & $55(29.3)$ & $17(9.0)$ & $95(50.5)$ & $R=-0.16$ \\
\hline 40 歳代 & 456 & $30.6 \%$ & $13(2.9)$ & $5(1.1)$ & $29(6.4)$ & $96(21.1)$ & $73(16.0)$ & $240(52.6)$ & $p<0.001$ \\
\hline 50 歳代 & 590 & $39.5 \%$ & $37(6.3)$ & $35(5.9)$ & $44(7.5)$ & $152(25.8)$ & $59(10.0)$ & $263(44.6)$ & \\
\hline 60 歳代 & 258 & $17.3 \%$ & $20(7.8)$ & $15(5.8)$ & 40 (15.5) & $73(28.3)$ & $14(5.4)$ & $96(37.2)$ & \\
\hline 小計 & 1492 & $100.0 \%$ & $71(4.8)$ & $64(4.3)$ & $124(8.3)$ & $376(25.2)$ & $163(10.9)$ & $694(46.5)$ & \\
\hline
\end{tabular}

表-3. 森林散策の好き嫌いと森林散策頻度との関連（男女別）

\begin{tabular}{|c|c|c|c|c|c|c|c|c|c|}
\hline \multirow[t]{2}{*}{ 頻度 } & \multicolumn{2}{|c|}{ 合計 } & 週 1 回以上 & 月 $2 \sim 3$ 回 & 月 1 回 & 年数回 & 年 1 回 & $\begin{array}{l}\text { ほとんど } \\
\text { 行かない }\end{array}$ & \multirow{2}{*}{$\begin{array}{l}\text { Spearman } の \\
\text { 相関係数 }\end{array}$} \\
\hline & $n$ & $\%$ & $\%$ & $\%$ & $\%$ & $\%$ & $n$ & $n \quad \%$ & \\
\hline 全体 & 4666 & $100.0 \%$ & $235(5.0)$ & $274(5.9)$ & $394(8.4)$ & $1227(26.3)$ & $486(10.4)$ & $2050(43.9)$ & \\
\hline \multicolumn{10}{|l|}{ 男性 } \\
\hline とても好き & 717 & $22.6 \%$ & $95(13.2)$ & $105(14.6)$ & $103(14.4)$ & $238(33.2)$ & $56(7.8)$ & $120(16.7)$ & $R=0.41$ \\
\hline どちらかと言えば好き & 1371 & $43.2 \%$ & $47(3.4)$ & $76(5.5)$ & $116(8.5)$ & $447(32.6)$ & $156(11.4)$ & $529(38.6)$ & $p<0.001$ \\
\hline 普通 & 987 & $31.1 \%$ & $21(2.1)$ & $28(2.8)$ & $48(4.9)$ & $161(16.3)$ & $106(10.7)$ & $623(63.1)$ & \\
\hline どちらかと言えば嫌い & 98 & $3.1 \%$ & $1(1.0)$ & $1(1.0)$ & $3(3.1)$ & $5(5.1)$ & $5(5.1)$ & $83(84.7)$ & \\
\hline とても嫌い & 1 & $0.03 \%$ & $0(0.0)$ & $0(0.0)$ & $0(0.0)$ & $0(0.0)$ & $0(0.0)$ & $1(100.0)$ & \\
\hline 小計 & 3174 & $100.0 \%$ & $164(5.2)$ & $210(6.6)$ & $270(8.5)$ & $851(26.8)$ & $323(10.2)$ & $1356(42.7)$ & \\
\hline \multicolumn{10}{|l|}{ 女性 } \\
\hline とても好き & 467 & $31.3 \%$ & $47(10.1)$ & $35(7.5)$ & $81(17.3)$ & $162(34.7)$ & $40(8.6)$ & $102(21.8)$ & $R=0.44$ \\
\hline どちらかと言えば好き & 577 & $38.7 \%$ & $15(2.6)$ & $23(4.0)$ & $30(5.2)$ & $161(27.9)$ & $84(14.6)$ & $264(45.8)$ & $p<0.001$ \\
\hline 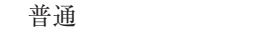 & 403 & $27.0 \%$ & $9(2.2)$ & $6(1.5)$ & $11(2.7)$ & $52(12.9)$ & $38(9.4)$ & $287(71.2)$ & \\
\hline どちらかと言えば嫌い & 44 & $2.9 \%$ & $0(0.0)$ & $0(0.0)$ & $2(4.5)$ & $1(2.3)$ & $1(2.3)$ & $40(90.9)$ & \\
\hline とても嫌い & 1 & $0.1 \%$ & $0(0.0)$ & $0(0.0)$ & $0(0.0)$ & $0(0.0)$ & $0(0.0)$ & 1（100.0） & \\
\hline 小計 & 1492 & $100.0 \%$ & $71(4.8)$ & $64(4.3)$ & $124(8.3)$ & $376(25.2)$ & $163(10.9)$ & $694(46.5)$ & \\
\hline
\end{tabular}

表-4. 年齢層別の森林散策の好き嫌い (男女別)

\begin{tabular}{|c|c|c|c|c|c|c|c|c|c|}
\hline & \multicolumn{2}{|c|}{ 合計 } & とても好き & $\begin{array}{l}\text { どちらかと } \\
\text { 言えば好き }\end{array}$ & 普通 & $\begin{array}{l}\text { どちらかと } \\
\text { 言えば嫌い }\end{array}$ & \multicolumn{2}{|c|}{ とても嫌い } & \multirow{2}{*}{$\begin{array}{l}\text { Spearman } の \\
\text { 相関係数 }\end{array}$} \\
\hline & $n$ & $\%$ & $n \quad \%$ & $n \quad \%$ & $\%$ & $n \quad \%$ & $n$ & $\%$ & \\
\hline 全体 & 4666 & $100.0 \%$ & $1184(25.4)$ & 1948 (41.7) & $1390(29.8)$ & $142(3.0)$ & 2 & $(0.04)$ & \\
\hline \multicolumn{10}{|l|}{ 男性 } \\
\hline 30 歳代 & 252 & $7.9 \%$ & 33 (13.1) & $116(46.0)$ & $91(36.1)$ & $12(4.8)$ & 0 & $(0.0)$ & $R=-0.12$ \\
\hline 40 歳代 & 937 & $29.5 \%$ & 175 (18.7) & $397(42.4)$ & $330(35.2)$ & $34(3.6)$ & 1 & $(0.1)$ & $p<0.001$ \\
\hline 50 歳代 & 1246 & $39.3 \%$ & $304(24.4)$ & $536(43.0)$ & $368(29.5)$ & $38(3.0)$ & 0 & $(0.0)$ & \\
\hline 60 歳代 & 739 & $23.3 \%$ & $205(27.7)$ & $322(43.6)$ & $198(26.8)$ & $14(1.9)$ & 0 & $(0.0)$ & \\
\hline 小計 & 3174 & $100.0 \%$ & $717(22.6)$ & $1371(43.2)$ & $987(31.1)$ & $98(3.1)$ & 1 & $(0.0)$ & \\
\hline \multicolumn{10}{|l|}{ 女性 } \\
\hline 30 歳代 & 188 & $12.6 \%$ & $55(29.3)$ & $71(37.8)$ & $53(28.2)$ & $9(4.8)$ & 0 & $(0.0)$ & $R=-0.19$ \\
\hline 40 歳代 & 456 & $30.6 \%$ & 97 (21.3) & 177 (38.8) & $165(36.2)$ & $16(3.5)$ & 1 & $(0.2)$ & $p<0.001$ \\
\hline 50 歳代 & 590 & $39.5 \%$ & $188(31.9)$ & $240(40.7)$ & $148(25.1)$ & $14(2.4)$ & 0 & $(0.0)$ & \\
\hline 60 歳代 & 258 & $17.3 \%$ & $127(49.2)$ & $89(34.5)$ & 37 (14.3) & $5(1.9)$ & 0 & $(0.0)$ & \\
\hline 小計 & 1492 & $100.0 \%$ & $467(31.3)$ & $577(38.7)$ & $403(27.0)$ & $44(2.9)$ & 1 & $(0.1)$ & \\
\hline
\end{tabular}

森林散策の好き嫌いと森林散策の頻度の関連について, 表-3に示す。好き（「とても好き」若しくは「どちらかと 言えば好き」：以下，「好き」とする）と回答した人は，全 体の $67.1 \%$ 占めていた。一方，嫌い（「とても嫌い」若 しくは「どちらかと言えば嫌い」）と回答した人は全体の 3.1\%にすぎなかった。男女での森林散策の好き嫌い（5 段
階）には差があり（ $p<0.001 ）$ ，女性の方が好きと回答し た割合は高かった。男女とも，森林散策が好きな人ほど高 い頻度で森林に行っていた。森林散策が好きと回答した人 （男性 2,088 人，女性 1,044 人）と, 普通と回答した人（男 性 987 人, 女性 403 人）を比較すると, 月 1 回以上森林散 策をしている人の割合は，男性では $26.0 \%$ と $9.8 \%$ （前者： 
好き，後者：普通，以下同様），女性では $22.1 \%$ と $6.5 \%$, 年 1 回以上森林散策をしている人の割合は，男性では 68.9\% と $36.9 \%$ ，女性では $64.9 \%$ と $28.8 \%$ であった。一方 で，森林散策が好きと回答した人でも，そのうちの $31.1 \%$ (男性)，もしくは $35.1 \%$ （女性）もの人が，ほとんど行か ないと回答していた。

森林散策の頻度は，年齢と森林散策の好き嫌いとに関連 があることが明らかになったため，さらに，森林散策の好 き嫌いと年齢との関連を検討した（表-4）。年齢と森林散 策の好き嫌いは，男女共に有意に弱い相関がみられた。概 ね高い年齢層の方が好きであるとした割合が高かったが, 女性の 30 歳代のみは逆の結果となり 40 歳代より好きと回 答した割合が高く，普通と回答した割合が低かった。

\section{IV. 考}

察

本調查の結果，半数以上の人が年 1 回以上，森林散策を 行っておう，約 2 割の人は月 1 回以上，森林散策を行って いることが明らかになった。内閣の世論調査からは，頻度 に関する情報は得られないものの, 年 1 回以上, 森林に行っ ている人の割合は推定でき，平成 19 年の調査では $72.7 \%$ であった。この世論調査の結果は，本調査における年 1 回 以上，森林散策に行く人の割合に比べ，約 20 ポイント高 かった（内閣府，2007）。これは，本調査では森林散策に 限定している一方, 内閣府の調査では，景観・風景を楽し むことや，スキーなど，森林散策以外の山間地域で行われ ているレジャーが含まれており，本調査より広範囲な野外 活動や観光などが含まれていたため，ということが考えら れる。

また，非就労者は就労者に比べ，森林散策頻度が高いこ とが明らかになった。本調査では森林散策の頻度と森林散 策の好き嫌い，森林散策の頻度と年齢には関連があり，非 就労者の方が，有意に森林散策を好きな人が多く，男女と もに年齢が高かったことが影響していた可能性もあるが, 非就労者は就労者に比べ自由になる時間が多く，より高い 頻度で，森林散策をすることができていたと考えられる。

大学演習林に来た人を対象とした調査 $(n=279$, 平均年 齢（SD） 53.2 (10.3）歳）では，週 1 回以上，森林に行っ ている人の割合は $9.0 \%$, 週 2 3 回は $21.1 \%$,月 1 回は $19.0 \%$ ，年数回は $39.1 \%$, 年 1 回は $7.5 \%$ ，ほとんど行か

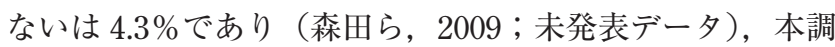
査の参加者は, 大学演習林に来た人よりも森林散策頻度が 低いことが明らかになった。本調查の方が一般集団に近 いと考えられるが, 森林散策の頻度が年数回以下の人が 80.6\%を占めており，これらの人をターゲットにして，よ り高い頻度で森林に来てもらえるようにすれば，健康づく りにも有益で, 中山間地域の活性化につながる可能性があ ると考えられる。

本研究の研究デザイン上の限界から, 因果関係を明らか にすることはできないが, 森林散策の好き嫌いは, 森林 散策頻度と関連がある要因の一つであることが明らかに
なった。大学演習林に来た人では，好きと回答した人は, $95.4 \%$ （本調査 $67.1 \%$ ), 普通は $4.0 \%$ （本調查 $29.8 \%$ ), 嫌いは $0.0 \%$ （本調査 $3.1 \%$ ）であり，本調查の対象者は, 大学演習林に来た人より, 森林散策が好きである人の割合 は低かった（Morita et al., 2007)。小規模な対象者数の研 究では, 森林に行くことにより, 森林がより好きになった という報告もあるため（森田ら，2008）, 森林散策が特に 好きではない人に森林に行く機会を設け，好きになっても らえれば, 中山間地域を訪れる機会も増える可能性がある。 一方で, 本調査の結果, 森林散策が好きと回答している のにも関わらず，そのうちの 3 割強の人が，ほとんど行か ないと回答していた。本調査では，好きにも関わらず，な ぜ森林散策をしていないのかを尋ねていないため, 理由を 明らかにすることはできなかった。今後，中山間地域振興 等のために, 八イカー, 保養客などの増加を期待する場合 には，これらの人に森林に来てもらうことが望ましく，な ぜ森林散策を行っていないのかという理由も含めた調査を 行い, 実現可能なことに関しては, 対策を講じる必要があ ると考えられる。

また，本調査は，一地域の住民のうちの人間ドッグ受診 者を対象に調査したため, 地域住民との差が生じている可 能性は否定できない。さらに, 他の地域の森林散策の頻度 は明らかではない。内閣府の世論調查でも, 年 1 回以上森 林に行っていると推定される人の割合は, 最も高い小都 市と最も低い東京都区部では約 15 ポイントの差があった。 ライフスタイルの違いに加え, 森林へのアクセスにより, 森林に行く人の割合や頻度に差が生じる可能性もある。到 達地である森林や公園からみた研究では, 誘致率はアクセ スに依存していることが報告されているため（大石, 2005; 國光, 2005 ; 山根, 1989 ; 青木ら, 1983 ; 宮林, 1978 ; 高 木・青木, 1970 ; 鈴木ら 1968 ; 近藤 1963), 逆に, 本調査 のように, 起点である地域の居住者を基準にした場合でも, 森林に行く頻度はアクセスに依存している可能性もある。 よって, 今後は, 地理的条件の異なった他の地域でも調查 をすることが望ましい。また, 今回の調査では, 34 歳以 下の人を対象にしていなかったが, 将来の森林散策者数の 動向を予測するためには, 本調査では対象としていなかっ た未青年層や青年層でも調查をすることが望ましい。また, 本調查では, 都市公園を除外していたが, 都市では公園が 緑と触れ合う場所になっているため, 今後は, 中山間地域 での森林散策頻度に加え, 都市公園の利用頻度も合わせて 調査することが望ましい。

上記のような限界はあるものの, 本調査の参加者は, 大 学演習林に来た人に比べ，森林散策の頻度は一般集団に近 いと考えられる。一般集団に近い集団での, 森林散策頻度 に関しての大規模な実態調査はほとんどない。本調查は, 世論調查の有効回答者の約 2.5 倍の参加者を得ており（内 閣府, 2003, 2007), 大規模な集団での森林散策の頻度の 一例を提供することができた。また, 大規模で行ったため, 森林散策頻度と関連がある要因について検討することが可 
能であった。その結果，森林散策頻度は，年齢や森林散策 の好き嫌いと関連していることを明らかにすることができ た。

今後は，都市公園の利用頻度も明らかにし，さらに，中 山村地域の地域活性のための基礎デー夕を得るために，他 地域や他の年齢層でも調査をすることが望ましいといえ る。

本研究は,「文部科学省特定領域研究「がん」分子疫学コー ホート研究の支援に関する研究」として研究助成を受けた。

\section{引用文献}

青木陽二・布施六郎・青木宏一郎（1983）公園緑地の種類と周辺条件 による誘致率の変化に関する研究 都内 6 公園における調査分析 結果より。造園雑誌 47: 112-118.

Asai, Y., Naito, M., Suzuki, M., Tomoda, A., Kuwabara, M., Fukada, H., Okamoto, A., Oishi, S., Ikeda, K., Nakamura, T., Misu, Y., Katase, S., Tokumasu, S., Nishio, K., Ishida, Y., Hishida, A., Morita, E., Kawai, S., Okada, R., Wakai, K., Tamakoshi, A., and Hamajima, N. (2009) Baseline data of Shizuoka Area in the Japan MultiInstitutional Collaborative Cohort Study (J-MICC Study). Nagoya J. Med. Sci. 71: 137-144.

近藤公夫 (1963) 自然休養地の休養率について 自然休養地の利用に関 する研究 (2). 造園雑誌 27: 7-10.

國光洋二（2005）住民の利用状況から見た農村親水公園の誘致圈域に 関する研究. 農村計画学会誌 4: 265-274.

宮林茂幸（1978）森林の厚生的機能の評価に関する研究（III）. 89 回 日林論 : 47-50.

Morita, E., Nagano, J., Yamamoto, H., Murakawa, I., Aikawa, M., and Shirakawa, T. (2009) Two thirds of forest walkers with Japanese cedar pollinosis visit forests even during the pollen season. Allergology International 58: 383-399.

森田えみ・永野 純・福田早苗・中島 皇・岩井吉彌・山本博一
浜島信之（2009）森林に行く頻度と主観的健康状態に関する横断 的研究. 日本生気象学会雑誌 46: 99-107.

森田えみ・池上博身 - 原田敬子 - 大原満枝 - 大平英樹 - 関山敦生 - 永 野 純・小杉眞司（2008）地域住民向けの連続型森林浴プログラ 么の評価。健康支援 10: 75-80.

Morita, E., Fukuda, S., Nagano, J., Hamajima, N., Yamamoto, H., Iwai, Y., Nakashima, T., Ohira, H., and Shirakawa, T. (2007) Psychological effects of forest environments on healthy adults: Shinrin-yoku (forest-air bathing, walking) as a possible method of stress reduction. Public Health 121: 54-63.

内閣府大臣官房政府広報室（2003）森林と生活に関する世論調査. 内 閣府.

内閣府大臣官房政府広報室（2007）森林と生活に関する世論調査. 内 閣府.

大石康彦（2005）白神山地地域に抢ける来訪者の特徵 暗門の滝, 白 神岳, 二ツ森における 1996〜 1997 年と 2001〜2002 年の来訪者を 対象に. 東北森林科学会誌 10: 8-16.

林野庁 (2007) 統計資料都道府県別森林率 - 人工林率. 林野庁.

林野庁 (2008) 森林・林業白書. $107 \mathrm{pp}$, 林野庁.

静岡県生活 - 文化部県民生活総室生活統計室（2006）市区町別推計人 口表. 静岡県.

鈴木忠義・渡辺貴介・森地 茂 (1968) 観光レクリエーション施設の 誘致圈に関する研究. 第 3 回都市計画学会学術研究論文集 : 4755.

高木勝久・青木尊重（1970）自然休養林に関する基礎的研究（II）到 達性についての一考察. 81 回日林講 : 53-55.

Takano, T., Nakamura, K., and Watanabe, M. (2002) Urban residential environments and senior citizens' longevity in megacity areas: the importance of walkable green spaces. J. Epidemiol. Commun. Health 56: 913-918.

The J-MICC Study Group (2007) The Japan Multi-Institutional Collaborative Cohort Study (J-MICC Study) to detect geneenvironment interactions for cancer. Asian Pac. J. Cancer Prev. 8: 317-323.

山根正伸（1989）都市近郊にある身近な森林利の利用と保全（I）神 奈川県厚木市の 3 つの森林の利用. 41 回日林関東支論 41: 17-20. 